\title{
A study on how age affects the relationship of Psychological Contract with Employee Involvement in the education sector
}

\author{
Priyanka Khurana * and Dr. Vaishali Sharma ** \\ * Ph D Scholar, Jagannath University, Jaipur \\ ** Professor, Jagannath University, Jaipur \\ DOI: 10.29322/IJSRP.11.12.2021.p12004 \\ http://dx.doi.org/10.29322/IJSRP.11.12.2021.p12004
}

\begin{abstract}
The aim of this paper to examine how the age of respondents effects the relationship psychological contract on employee involvement in education sector of India. This study is descriptive as well as diagnostic in nature which focuses on quantitative methods to understand the relationship of psychological contracts with employees' involvement based upon the age of the selected respondents. The data for this study was collected using two sets of questionnaires filled by full time teaching staff as well as from their employers, respectively belonging from public and private sector higher education institutes of Delhi NCR region. The total sample size for this research is 493. Pearson's Chi-Square test was applied to analyze the relationship of psychological contract and employee involvement for different age groups taken into consideration. The findings of the study suggests that for public sector in the case of young respondents, i.e. those between the ages of 25 and 30 years as well as $30-35$ years, the main item of employee involvement that has directly impacted the psychological contract is openness to feedback/suggestions/opinion, and initiative is another item that has less impact on the psychological contract of respondents. For 35 - 40 years respondents, communication and openness to feedback/suggestions/opinion are the main items of employee involvement that have directly impacted the psychological contract. Participation in decision making is another item that has less impact on the psychological contract. Initiative, freedom to be creative, and openness to feedback/suggestions/opinion are the main items of employee involvement that have directly impacted the psychological contract of the respondents of over 40 years of age, while participation in decision making and platform for recreational activities have less impact on the psychological contract.
\end{abstract}

For private sector young respondents i.e. belonging to $25-30$ years, the key items of employee involvement that have directly impacted the psychological contract in the private sector are freedom to be creative and openness to feedback/suggestions/opinion. The key aspect of employee involvement that has directly impacted the psychological contract is being open to feedback/suggestions/opinion for respondents in the $30-35$ year age group. For $35-40$ years respondents, the main item of employee involvement that has directly impacted the psychological contract of respondents is openness to feedback/suggestions/opinion, and participation in decision making is another item that has less impact on the psychological contract.

The freedom to be creative and being open to feedback/suggestions/opinion are the key components of employee involvement that have directly impacted the psychological contract for respondents over 40 years old.

Academics and researchers will learn from the study's results that psychological contract expectations affect employee involvement expectations differently for different age groups in the education sector. This study also offers policy recommendations and practical advice to educational leaders on how to promote employee engagement in their organizations.

Keywords: Age, employee involvement, higher education sector, psychological contract.

\section{INTRODUCTION}

In $21^{\text {st }}$ century, the main task for any organization is to manage as well as retain its competent and skilled workforce as the key human resources have been proven as source of gaining competitive advantage and an edge over their competing organizations. Earlier the people get satisfied with financial earnings and other monetary benefits but now a days, the scenario has been changed substantially, as the demands of the employees has been shifted to non-monetary benefits along with monetary benefits also. Their demands are changing to recognition, health benefits, and opportunities for personal growth. In this context, Psychological contracts have become a powerful tool for understanding the relationship of employees with their respective employers. Many research scholars have already accepted in their previous researches that fulfilment of psychological contract can be linked with many benefits in the organization

The term psychological contract can be differentiated from hard contracts as such legal contract that includes a definition of the employers' and organization's roles, obligations, and duties where as soft contracts or psychological contracts are implicit, unexpressed and unwritten in nature.

"The psychological contract is individual beliefs, created by the organization, regarding parameters of an exchange arrangement between the individual and their organization," according to one 
prominent explanation of the phrase coined by Rousseau (1995: 9).

There are numerous variations that describe the nature of these soft agreements, such as the fact that these mutual contracts are subjective, as the same set of expectations may be inferred by the individual in a different way depending on the people's perception. Individuals determine their duties in their own way due to variances in views and attitudes, hence such contracts are highly subjective and unique.

Because there is always an exchange of expectations between two parties (employer and employee) in a work relationship, psychological contracts are reciprocal. When both parties fulfil their commitments, it is considered psychological contract fulfilment.

Psychological contracts are "unwritten, unexpressed set of expectations," according to Schein (1965). The key aspects of psychological contracts that are implicit are expectations that are uttered but not written on paper, stay in the thoughts of individuals, and are not formally defined by the employer or employee.

Soft contracts often have serious consequences if breached in organizations, so psychological contracts function in a similar manner to hard contracts, implying the obligatory nature of psychological contracts.

As a result, the psychological contract content is always based in the implicit terms \& conditions exchanged between the two parties rather than mutual understanding. The obligations of the employee will be fulfilled by the employer, which in turn will reflect the expectation to be met by the employee.

Psychological contracts are classified as Relational, Transactional, Balanced, and Transitional as per their nature. Relational soft contracts are very subjective and open-ended. There is a high level of reciprocal dependency between employee and employer, as well as a number of impediments to relationship termination. Employees and employers put in a lot of effort to keep their working relationships strong. These contracts have emotional components and are vulnerable to change due to their dynamic nature. They are most commonly found in family-owned enterprises. Transaction contracts include a bunch of distinct terms and states of the exhibition in return for cash. They are shaped for a brief period with negligible inclusion of individual viewpoints significantly focusing on the utilization of the prior information and abilities. These delicate agreements are very inflexible and exist for the authoritative and off-site workers. Another element of these shared connections is transitional contracts in which there exist immense vulnerability, question and uncertainty about the positions and conditions. These sorts of connections exist during the phase of consolidations or acquisitions in the economy. The turnover proportion of such delicate agreements is very high because of hazy trade terms of commitments. In contrast, welldefined employment terms and circumstances of mutually existing employee-employer relationships are included in balanced contracts. These are open-ended contracts that are centered on the employees' overall development and advancement. The participants of the connection are united by a strong sense of teamwork, mutual trust, and commitment. Because of the economy's characteristics, the balanced contract occurs in most professionally managed firms and public sector businesses.

This publication is licensed under Creative Commons Attribution CC BY

http://dx.doi.org/10.29322/IJSRP.11.12.2021.p12004
Psychological contracts or soft contracts formed via continuing interactions between employees and employers impact employee involvement in the organizations. Employee happiness is the outcome of mutual expectations being satisfied, which leads to increased involvement, which is linked to the productivity of the company. Employee involvement can be understood as that large number of drives made by the organization which interface the human resources with the organization's operations. Simple procedures such as having an open door policy or a suggestion box system, sharing any plan with teammates, or larger decisions such as quality circles or total quality management are examples of this. The level of employee involvement in an organizational structure varies depending on the employee's designation as well as the level of involvement expected by top-level management. When only basic opinions or suggestions for new policy development are required from low-level employees, the management may use policies such as a suggestion box, open discussions, or surveys, whereas when moderate employee involvement is required from middle-level employees or functional heads, the organization usually forms a participative management committee, lean systems, or task force that focuses on continuous improvement. In the case of top-level management, when there is always a need for evaluating employees' performance, formulating policies, or implementing any new plan, the company provides highly controlled self-teams and employee ownership.

Employee involvement is now a must-have in order for an organization to maximize the potential of its human resources in terms of performance. Employee involvement not only aids top management in achieving their objectives, but it also aids employees in honing their skills, pacing their work operations, thinking outside the box, and innovating products and services. Employee involvement, according to historical research, leads to a motivated workforce, a positive attitude, and improved employee performance, which improves the financial productivity of the firm (Houger, 2006).

\section{LITERATURE REVIEW}

The understanding of employment relationships has been a topic of study everywhere in the twenty-first century, therefore the notion of psychological contract is frequently used to relate the relationship between employers and employees. According to Kessler \& Coyle Shapiro (1998), scholars' interest in this notion arose in the United States during a period of business reorganization and downsizing. Employee involvement is the need of the hour nowadays, according to Ruokolainen et al., (2016), since it allows the business to best leverage the capabilities of its human resources into performance. In his book "Theory of Psychoanalytic Technique," Menninger (1958) first discussed the conceptual meaning of the term "psychological contract."

Levinson (1962), the concept's father, characterized a psychological contract as an "unwritten contract, the sum of the mutual expectations between the business and its employees" (Agarwal \& Gupta, 2016). These expectations based on mutual trust are referred to as "components" of the psychological contract, and they are largely implicit and unspoken, rather than needing to be comprehended by employees and employees based on their views. Furthermore, expectations predate or arise before to entering the business, and they change constantly due to the changing requirements or desires of employees or bosses. Job 
satisfaction, organisational commitment and loyalty, employee engagement, organisational citizenship behaviour, quality of work, and employee turnover are all outcomes of psychological contract fulfilment ("Employee Workplace Safety, Job Satisfaction, and Organizational Commitment," 2019; Pouramini \& Fayyazi, 2015; Kholiq \& Miftahuddin, 2019).

Martin et al. (1998) compared the expectations of white-collar and blue-collar employees and discovered a significant variation in their responsibilities and training requirements. The management expected training sessions to help them grow and stay with the company, whereas the factory workers wanted training to help them improve their technical abilities and find a better position.

Kickul \& LiaoTroth (2003) investigated the impact of climate perceptions on the psychological contract and proposed that employees' attitudes regarding their workplace are favorably related to soft contract responsibilities. The psychological contract components of workload and role clarity can be linked to the work environment, which also clarifies the job of the employees. Employees that have a favorable attitude toward their colleagues and superiors and have a positive perspective of their psychological contract fulfilment feel proud and respected within the organization and express openness, two-way communication, and show respect for their employers.

Dainty et al. (2004) conducted research to better understand the psychological contracts of managers at various levels of the company. Managers at all levels of the hierarchy expressed comparable feelings about their psychological contracts, but the causes for their feelings were completely different. Some managers had reasonable expectations and cited a lack of resources as a primary factor, whereas others had emotional expectations and were unsatisfied with their employers owing to prejudiced treatment they had received, and the management turned careless at times.

Cuyper \& Witte (2006) investigated how uncertainties about workplaces and contract types affect employee engagement and satisfaction. To get them involved, their soft contracts can be converted into relational psychological contracts.

When both workers and employers analyze the changing nature of their obligations, they can misunderstand their evolving obligations, and such disagreements between them lead to breach of soft contracts (Lester et al., 2007). The duties of psychological contracts are heavily influenced by the passage of time.

Psychological contract fulfillment can be correlated with the support of an organization that is perceived to provide services related to its employees and their roles, as well as the behavior of the organization's citizens. Awareness of the performance of generalized reciprocal behavior has a positive impact on the perceived psychological performance, emotional commitment, and intention to leave the contract (Guerrero \& Herrbach, 2008).

Webster \& Adams, (2009) analyzed the relationship between favorable work status and non-job performance and, in the case of psychological contract fulfillment, have a positive impact on favorable work status within the organization and non-work performance while no such impacts were discovered during the role performance study.

Blomme et al. (2010) looked into the link between psychological contract and affective commitment. As affective commitment is one of the strongest predictors of the connection between psychological contract and turnover intentions, the relationship between various measures like job content, career development opportunities, work culture, growth \& promotion opportunities, and affective commitment $\&$ intention to quit was moderate to strong.

Parzefall \& Coyle-Shapiro (2011) investigates the factors that cause psychological breach of contracts, and in the absence of mutual trust, organizational support or support from superiors, employees are psychologically breached. Of the contract it was found tended to initiate negative behavior. When an intentional breach occurs, the consequences are more severe than when other legitimate circumstances or misunderstandings occur.

Conway \& Coyle Shapiro (2012) analyzed the value of timeframes to understand the complex relationships between workers and employers within an organization. Over time, the fulfillment of soft contractual obligations had a strong positive impact on employees and employers, which in turn had an impact on employee performance.

The impacts of trust and psychological contract breach on authentic leadership and organizational deviance were studied by Erkutlu and Chafra (2013), who discovered a negative association between authentic leadership and trust and psychological contract breach. There was less of a link between authentic leadership and organizational deviance among higher-ranking employees who trusted their bosses. In the case of psychological contract breach, authentic leadership and organizational deviance were found to have a negative yet robust link. There is a strong link between benevolent leadership and psychological well-being, therefore psychological contract breaches are more often. Fair treatment by employers has been shown to influence employees' attitudes and behaviors in terms of their commitment to the company. As a result, managers must receive official training on how to handle their junior staff fairly and respectfully.

Employee participation was positively mediated by training supplied to them, however training had a negative impact on employee weariness, according to Santos Cesário et al., (2014), who investigated how training and exhaustion can be connected with psychological contract fulfilment. Employee obligations might be linked to training and weariness in a beneficial way. Employees' organizational emotional commitment and job satisfaction were associated to psychological contract fulfilment (Santos Cesário et al., 2014b).

The impact of the psychological contract, relational psychological contract, and transactional psychological contract on organizational commitment as mediated by transactional leadership was investigated by Jabeen et al. (2015), who proposed that both relational and transactional psychological contracts predict the content of psychological contract formation and represent employees' commitment to their organizations. As a result, businesses are putting a greater emphasis on supporting HR practices that aid in the formation of psychological contracts between employees and employers. There will be a significant change in employee behavior if efforts are made to develop transactional psychological contracts.

Chambel et al. (2016) looked at the relationship between the psychological contract of permanent and temporary agency workers and their levels of work engagement, and discovered that transactional PC prevails among temporary agency workers, but relational/balanced PC exists among permanent workers. Temporary agency workers were found to have more 
psychological contract fulfilment than permanent employees, with the same level of involvement in both circumstances.

The organization's work environment, such as peer and superior support, possibilities for creativity and innovation, all play a role in forecasting psychological contract fulfilment (Agarwal \& Farndale, 2017). Transformational leadership, work satisfaction, and commitment were all found to be predictors of the formation of relational psychological contracts, while transformational leadership and compensation were found to be predictors of the production of transactional psychological contracts (Syrek \& Antoni, 2017).

Job security, mutual trust, and employee friendliness can all be used as predictors of employee motivation in a business, with a negative influence on employee motivation if these duties are not met (Singhvi et al., 2018). In the event of a psychological contract violation, older employees are more likely to leave their company, but newer employees are more likely to stay with their coworkers to retain their ties (Li \& Chen, 2018).

Sandhya and Sulphey (2019) examined the impact of psychological contracts on employees and found that if perceived

\section{RESEARCH METHODOLOGY}

The target sample selected for the study is of 493 respondents (including teaching staff and managerial personnel) from higher education institutes of Delhi NCR region. The sample has been categorized into two separate categories: private sector (262 respondents) and public sector (231 respondents). Data has been collected using a properly structured two-part questionnaire to be filled by full time teaching staff (Part - A) as well as their respective employers (Part $-\mathrm{B}$ ) from the selected organizations. In the public sector, 200 questionnaires (Part - A) and 31 questionnaires (Part - B), whereas in the private sector, 230 questionnaires (Part - A) and 32 questionnaires (Part - B) were used. A cluster sampling strategy was employed to choose educational schools in Delhi NCR, and geographical clusters were established to properly represent the intended sample for the study. Respondents from the geographical clustered samples were chosen using a judgmental sampling approach.

The null and alternate hypotheses for the study are as follows:

$\mathrm{H} 1_{0}=$ There is no significant difference in the effect of Employee Involvement due to Psychological Contract based upon the age of employees in higher education sector.

$\mathrm{H} 1_{\mathrm{A}}=$ There is a significant difference in the effect of Employee Involvement due to Psychological Contract based upon the age of employees in higher education sector.

\section{ANALYSIS AND INTERPRETATION}

\section{Demographical profile of Public sector (Part-A Sample)}

According to table 1, males account for $41 \%$ of the sample population in the public sector, while females account for the remaining $59 \% .90 .5 \%$ of the sample population is married, with only $9.5 \%$ of public sector respondents being unmarried. $64 \%$ of respondents in this industry have a $\mathrm{Ph}$. D., $25 \%$ are postgraduates in their respective disciplines, and the other $11 \%$ have either an $\mathrm{M}$. Phil degree or are NET qualified (considered in the "Others" employee commitments are met, it has positive and motivating effects, such as increased employee engagement activities, thus reducing employee income intentions. Fulfillment of the psychological contract also results in a number of beneficial health effects such as improved mental health, positive attitudes in the organization.

Supramaniam et al., (2020b) investigated the relationship between talent management practices and the psychological contract and discovered that there is a strong and positive relationship between talent management practices and the psychological contract, indicating that well-managed talent management practices lead to stronger psychological contracts for employees.

Hameed et al., (2021) conducted a study on the performance of psychosocial contracts in academia and found that aspects of equity promotion, consultation, recognition of contributions, which provides funding research and equal pay for equal work, compliance with psychological contracts is very low. As a result, there are pressures at work, mutual mistrust and psychologically weak contracts.

category). The majority of the respondents in the sample population are over 35 years old, $34.5 \%$ of the entire sample population is between the ages of 35 and 40, with respondents older than 40 filling out $41 \%$ of the questions. Only $8.5 \%$ of the sample population is between the ages of 25 and 30, whereas 16 $\%$ of the respondents are between the ages of 30 and 35 .

Table 1: Demographics of public sector (Part - A)
\begin{tabular}{|l|l|}
\hline Demographic characters & Total \% of respondents \\
\hline Gender & \\
Male & 41 \\
Female & 59 \\
\hline Marital Status & \\
Unmarried & 9.5 \\
Married & 90.5 \\
\hline Education Qualification & \\
Post graduate & 25 \\
Ph. D & 64 \\
Others & 11 \\
\hline Age & \\
25-30 years & 8.5 \\
$30-35$ years & 16 \\
35-40 years & 34.5 \\
Above 40 years & 41 \\
\hline
\end{tabular}

Demographical profile of Public sector (Part - B Sample)

As per table 2, males account for $41.9 \%$ of the sample population who completed Part-B questionnaires, while females account for $58.1 \%$. $93.5 \%$ of the public sector sample population that completed Part B of the surveys is married, whereas just $6.5 \%$ of the respondents are unmarried. The majority of responders in this industry have a $\mathrm{Ph}$. D degree, $12.9 \%$ are postgraduates in their respective disciplines, and the remaining $9.7 \%$ are considered in the "Others" category. The majority of the sample population's responders are above 40 years old. $40 \%$ of the total sample population is over 40 years old, while respondents between the ages of 35 and 40 fill out $12.9 \%$ of the surveys.

Table 2: Demographics of public sector (Part - B) 


\begin{tabular}{|l|l|}
\hline Demographic characters & Total \% of respondents \\
\hline Gender & \\
Male & 41.9 \\
Female & 58.1 \\
\hline Marital Status & \\
Unmarried & 6.5 \\
Married & 93.5 \\
\hline Education Qualification & \\
Post graduate & 12.9 \\
Ph. D & 77.4 \\
Others & 9.7 \\
\hline Age & \\
35-40 years & 12.9 \\
Above 40 years & 87.1 \\
\hline
\end{tabular}

Demographical profile of Private sector (Part - A Sample)

As per table 3, in private sector males account for $39.6 \%$ of the sample population who completed Part-A surveys, while females account for the remaining $60.4 \%$ of the sample population. Only $5.2 \%$ of the respondents who filled out Part - A of the questionnaires are unmarried, despite the fact that $94.8 \%$ of the sample population is married. $62.6 \%$ of respondents have a $\mathrm{Ph}$. D., $28.3 \%$ are postgraduates in their specialties, and the remaining $9.1 \%$ are considered in the "Others" category. The majority of the sample population's responders are above 35 years old. $33.9 \%$ of the entire sample population is between the ages of 35 and 40 , and $38.7 \%$ of the questionnaires are completed by respondents over the age of $40.12 .2 \%$ of the sample population is between the ages of 25 and 30 , and $15.2 \%$ of the respondents are between the ages of 30 and 35 years.

Table 3: Demographics of private sector $($ Part $-\mathbf{A})$

\begin{tabular}{|l|l|}
\hline Demographic characters & Total \% of respondents \\
\hline Gender & \\
Male & 39.6 \\
Female & 60.4 \\
\hline Marital Status & \\
Unmarried & 5.2 \\
Married & 94.8 \\
\hline Education Qualification & \\
Post graduate & 28.3 \\
Ph. D & 62.6 \\
Others & 9.1 \\
\hline Age & \\
25-30 years & 12.2 \\
30-35 years & 15.2 \\
35-40 years & 33.9 \\
Above 40 years & 38.7 \\
\hline
\end{tabular}

Demographical profile of Private sector (Part-B Sample)

As per table 4, $31.3 \%$ of the sample population that filled out the Part - B questionnaires is male, while the remaining $58.8 \%$ is female in the private sector. $93.8 \%$ of the sample population is married, while just $6.2 \%$ of the respondents who filled out Part $\mathrm{B}$ of the questionnaires are unmarried. $62.5 \%$ of respondents in this industry have a Ph. D., $31.3 \%$ are postgraduates in their areas, and the remaining $6.2 \%$ are considered in the "Others" category.

Table 4: Demographics of public sector (Part - B)

\begin{tabular}{|l|l|}
\hline Demographic characters & Total \% of respondents \\
\hline Gender & \\
Male & 31.3 \\
Female & 68.8 \\
\hline Marital Status & \\
\hline
\end{tabular}

This publication is licensed under Creative Commons Attribution CC BY. http://dx.doi.org/10.29322/IJSRP.11.12.2021.p12004

\begin{tabular}{|l|l|}
\hline Unmarried & 6.3 \\
Married & 93.8 \\
\hline Education Qualification & \\
Post graduate & 31.3 \\
Ph. D & 62.5 \\
Others & 6.3 \\
\hline Age & \\
35-40 years & 78.1 \\
Above 40 years & 28.9 \\
\hline
\end{tabular}

\section{Cronbach's Alpha Reliability test}

To ensure that the sample data was reliable, Cronbach's Alpha test was used to each of the data sets for both sectors. Each data set's Cronbach's coefficient is greater than 0.7 , which is acceptable.

\section{Hypothesis testing}

The psychological contract items were derived from the questionnaire to evaluate the hypothesis, such as approach, fair treatment, opportunity for personal growth, and so on. Components of employee involvement, such as communication and initiatives, were created in the same way. In both the public and private sectors, Pearson's Chi Square test for independence was performed for the different age categories to determine the statistical difference between anticipated and actual values in the contingency table, and the results are presented in the table 5.

Table 5: Pearson's Chi-Square test's results for the age group 25 - 30 years Part - A (public sector)

\begin{tabular}{|l|l|l|}
\hline PC Variable items & E I variable items & $\begin{array}{l}\text { p-value (25 - 30 } \\
\text { years) }\end{array}$ \\
\hline Q1 (Approach) & Q2 (Communication) & 0.612 \\
\hline Q1 (Approach) & $\begin{array}{l}\text { Q5 (Participation in decision } \\
\text { making) }\end{array}$ & 0.74 \\
\hline Q1 (Approach) & Q7 (Initiatives) & 0.482 \\
\hline Q1 (Approach) & Q8 (Freedom to be creative) & 0.098 \\
\hline Q1 (Approach) & $\begin{array}{l}\text { Q11 (Feedback / Suggestion / } \\
\text { Opinion) }\end{array}$ & $<\mathbf{0 . 0 0 1}$ \\
\hline Q3 (Fair treatment) & Q2 (Communication) & 0.612 \\
\hline Q3 (Fair treatment) & $\begin{array}{l}\text { Q5 (Participation in decision } \\
\text { making) }\end{array}$ & 0.74 \\
\hline Q3 (Fair treatment) & Q7 (Initiatives) & 0.482 \\
\hline Q3 (Fair treatment) & Q8 (Freedom to be creative) & 0.098 \\
\hline Q3 (Fair treatment) & $\begin{array}{l}\text { Q11 (Feedback / Suggestion / } \\
\text { Opinion) }\end{array}$ & $<\mathbf{0 . 0 0 1}$ \\
\hline $\begin{array}{l}\text { Q4 (Opportunity for } \\
\text { personal growth) }\end{array}$ & Q2 (Communication) & 0.429 \\
\hline $\begin{array}{l}\text { Q4 (Opportunity for } \\
\text { personal growth) }\end{array}$ & $\begin{array}{l}\text { Q5 (Participation in decision } \\
\text { making) }\end{array}$ & 0.813 \\
\hline $\begin{array}{l}\text { Q4 (Opportunity for } \\
\text { personal growth) }\end{array}$ & Q7 (Initiatives) & $\mathbf{0 . 0 2 4}$ \\
\hline $\begin{array}{l}\text { Q4 (Opportunity for } \\
\text { personal growth) }\end{array}$ & Q8 (Freedom to be creative) & 0.364 \\
\hline $\begin{array}{l}\text { Q4 (Opportunity for } \\
\text { personal growth) }\end{array}$ & $\begin{array}{l}\text { Q11 (Feedback / Suggestion / } \\
\text { Opinion) }\end{array}$ & 0.15 \\
\hline Q6 (Recognition) & Q2 (Communication) & 0.612 \\
\hline $\begin{array}{l}\text { Q6 (Recognition) } \\
\text { Q5 (Participation in decision } \\
\text { making) }\end{array}$ & 0.74 \\
\hline Q6 (Recognition) & Q7 (Initiatives) & 0.482 \\
\hline Q6 (Recognition) & Q8 (Freedom to be creative) & 0.098 \\
\hline $\begin{array}{l}\text { Q6 (Recognition) } \\
\text { O11 (Feedback / Suggestion / }\end{array}$ & $<\mathbf{0 . 0 0 1}$ \\
\hline
\end{tabular}




\section{RESEARCH FINDINGS}

The key factors of employee involvement for respondents in the age bracket of 25-30 years include freedom to be creative and open to feedback/suggestions/opinion, as well as some additional items like initiative, which have a relationship with their perceived psychological contract.

The key component of employee involvement for respondents in the 30-35 year age group is open for feedback/ suggestions/ opinion that has a relationship with their perceived psychological contract.

The key factors of employee involvement for respondents in the 35-40 year age group include communication and openness to feedback/ suggestions/ opinion, as well as some additional variables like participation in decision making, which have a relationship with their perceived psychological contract.

The main items of employee involvement for respondents over 40 years old are initiative, freedom to be creative, and openness to feedback/suggestions/opinion, as well as some other items like participation in decision-making and a platform for recreational activities, all of which have a relationship with their perceived psychological contract.

Because the factors of employee involvement that have a relationship with the perceived psychological contract varies in the higher education sector with different age groups, $\mathrm{H}_{0} 1_{0}$ is rejected and $\mathrm{H}_{\mathrm{A}}$ is accepted, which states that

$\mathrm{H} 1_{\mathrm{A}}=$ There is a significant difference in the effect of Employee Involvement due to Psychological Contract based upon the age of employees in higher education sector.

\section{CONCLUSION}

According to the study, as employees' ages increase, their expectations of their employers in the Indian higher education industry shift. Younger employees, those between the ages of 25 and 30, anticipate possibilities for initiative and the ability to be creative in their work styles. Employees in the age range of $30-$ 35 years change their focus to openness to feedback, recommendations, and opinion, and employees in the age group of 35 - 40 years want participation in decision-making. Older employees, those over the age of 40 , have all of the above expectations, as well as a desire for a platform for recreational activities. The achievement of these goals is inextricably linked to their participation in the organization.

\section{APPENDIX}

The appendixes attached in the last for the reference.

\section{ACKNOWLEDGMENT}

We express our thanks to the faculty members of Jagannath University, Jaipur for their immense support and help required for the research work.

We would like to express our sincere gratitude to all the participant organizations in Delhi/NCR region, which extended their support during my data collection.
We are extremely grateful to our respective families for being cooperative throughout the research.

\section{REFERENCES}

[1] Agarwal, P., \& Farndale, E. (2017). High-performance work systems and creativity implementation: the role of psychological capital and psychological safety. Human Resource Management Journal, 27(3), 440458. https://doi.org/10.1111/1748-8583.12148

[2] Chambel, M. J., Lorente, L., Carvalho, V., \& Martinez, I. M. (2016). Psychological contract profiles among permanent and temporary agency workers. Journal of Managerial Psychology, 31(1), 79-94. https://doi.org/10.1108/jmp-02-2014-0070

[3] Conway, N., \& Coyle-Shapiro, J. A. M. (2011). The reciprocal relationship between psychological contract fulfilment and employee performance and the moderating role of perceived organizational support and tenure. Journal of Occupational and Organizational Psychology, 85(2), 277-299. https://doi.org/10.1111/j.2044-8325.2011.02033.x

[4] Cuyper, N., \& Witte, H. (2006). The impact of job insecurity and contract type on attitudes, well-being and behavioural reports: A psychological contract perspective. Journal of Occupational and Organizational Psychology, 79(3), 395-409. https://doi.org/10.1348/096317905x53660

[5] Dainty, A. R., Raiden, A. B., \& Neale, R. H. (2004). Psychological contract expectations of construction project managers. Engineering, Construction and Architectural Management, 11(1), 33-44. https://doi.org/10.1108/09699980410512647

[6] Erkutlu, H., \& Chafra, J. (2013). Effects of trust and psychological contract violation on authentic leadership and organizational deviance. Management Research Review, 36(9), 828-848. https://doi.org/10.1108/mrr-06-2012$\underline{0136}$

[7] Guerrero, S., \& Herrbach, O. (2008). The affective underpinnings of psychological contract fulfilment. Journal of Managerial Psychology, 23(1), 4-17. https://doi.org/10.1108/02683940810849639

[8] Hameed, I., Ijaz, M. U., \& Sabharwal, M. (2021). The Impact of Human Resources Environment and Organizational Identification on Employees' Psychological Well-Being. Public Personnel Management, 009102602110013. https://doi.org/10.1177/00910260211001397

[9] Inam Ul Haq. (2011). Psychological contract and job outcomes: mediating role of affective commitment. African Journal of Business Management, 5(19). https://doi.org/10.5897/ajbm10.1617

[10] Jabeen, F., Behery, M., \& Abu Elanain, H. (2015). Examining the relationship between the psychological contract and organisational commitment. International Journal of Organizational Analysis, 23(1), 102122. https://doi.org/10.1108/ijoa-10-2014-0812

[11] Katelyn H. Kim. (2017). The Effect of Transformational Leadership \& Transactional Leadership on Organizational Commitment - Mediating Role of Self-Efficacy \& Psychological Contract -. Tourism Research, 42(3), 4765. https://doi.org/10.32780/ktidoi.2017.42.3.47

[12] Kholiq, D. A., \& Miftahuddin, M. (2019). Effect Of Job Embeddedness, Job Satisfaction, And Organizational Commitment On Employee Turnover Intention. TAZKIYA: Journal of Psychology, 5(1). https://doi.org/10.15408/tazkiya.v22i1.8154

[13] Kickul, J., \& Liao-Troth, M. A. (2003). The Meaning Behind the Message: Climate Perceptions and the Psychological Contract. American Journal of Business, 18(2), 23-32. https://doi.org/10.1108/19355181200300009

[14] Lester, S. W., Kickul, J. R., \& Bergmann, T. J. (2007). Managing employee perceptions of the psychological contract over time: the role of employer social accounts and contract fulfillment. Journal of Organizational Behavior, 28(2), 191-208. https://doi.org/10.1002/job.410

[15] Li, S., \& Chen, Y. (2018). The Relationship Between Psychological Contract Breach and Employees' Counterproductive Work Behaviors: The Mediating Effect of Organizational Cynicism and Work Alienation. Frontiers in Psychology, 9. https://doi.org/10.3389/fpsyg.2018.01273

[16] Parzefall, M., \& Coyle-Shapiro, J. A. (2011). Making sense of psychological contract breach. Journal of Managerial Psychology, 26(1), 12-27. https://doi.org/10.1108/02683941111099592

[17] Sandhya, S., \& Sulphey, M. (2019). An assessment of contribution of employee engagement, psychological contract and psychological empowerment towards turnover intentions of IT employees. International 
Journal of Environment, Workplace and Employment, 5(1), 22. https://doi.org/10.1504/ijewe.2019.097186

[18] Santos Cesário, F., José Chambel, M., \& Guillén, C. (2014). What if expatriates decide to leave? The mediation effect of the psychological contract fulfilment. Management Research: The Journal of the Iberoamerican Academy of Management, 12(2), 103-122. https://doi.org/10.1108/mrjiam-08-2013-0516

[19] Singhvi, P. A. S., Dhage, N. N., \& Sharma, P. P. (2018). Compensation and Its Impact on Motivation Employee se Satisfaction and Employee $s$ Performance. International Academic Journal of Organizational Behavior and Human Resource Management, 05(02), 1-43. https://doi.org/10.9756/iajobhrm/v5i2/1810012

[20] Supramaniam, M., Muniandi, T., T, R., Mohamed, R. K. M. H., Subramaniam, V., \& Begum, M. (2020). The relationship between Human Resource Management Practices, Psychological Contract and Innovative Behaviours of Academicians. International Journal of Psychosocial Rehabilitation, 24(02), 2477-2489. https://doi.org/10.37200/ijpr/v24i2/pr200544
[21] Webster, J. R., \& Adams, G. A. (2009). Organizational Support and Contract Fulfillment as Moderators of the Relationship Between Preferred Work Status and Performance. Journal of Business and Psychology, 25(1), 131138. https://doi.org/10.1007/s10869-009-9135-Z

\section{AUTHORS}

First Author - Priyanka Khurana, Ph. D Scholar, Jagannath University Jaipur, Priyanka.khurana19@gmail.com.

Second Author - Dr. Vaishali Sharma, qualifications, Jagannath University Jaipur, vaishali.sharma@ jagannathuniversity.org

Correspondence Author $\quad-\quad$ Priyanka
Priyanka.khurana19@gmail.com, 9711507800.


Appendix I RESEARCH QUESTIONNAIRE

\section{Psychological Contract Questionnaire (Part A) (Employee's obligations towards Employers)}

SECTION A (Demographic and some other characteristics)

1. Email Id:

2. Name of the organization:

3. Name of the respondent:

4. Designation:

5. Year of joining the organization:

6. Gender: Male

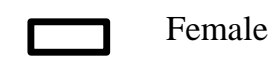

7. Marital Status:

Unmarried

Married

Other

8. Educational Qualification: Graduate

Post Graduate

$\mathrm{Ph} D \square$ Others

9. Age: 25 - 30 years

30 - 35 years

$35-40$ years

Above 40 years

10. In which sector are you working?

Public Sector $\square$

Private Sector

Semi - Government Sector

11. Total working experience:

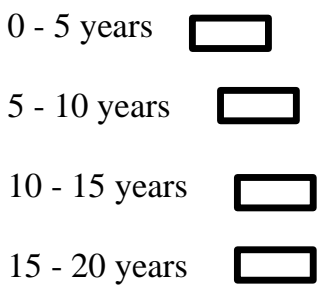

More than 20 years

12. Number of organizations worked for prior to this organization:
$0-3$
$3-5$
More than 5

\section{SECTION B}

The following table contains items measuring Employees' Commitment/Obligation towards Employers. Please tick the degree to which you think the following statements are applicable for you / in your organization:

\begin{tabular}{|ccccc|}
\hline 1 & 2 & 3 & 4 & 5 \\
Strongly disagree & Disagree & Neutral & Agree & Strongly agree \\
\hline
\end{tabular}

\begin{tabular}{|l|l|l|l|l|l|l|}
\hline S. No. & Obligations & 1 & 2 & 3 & 4 & 5 \\
\hline
\end{tabular}

This publication is licensed under Creative Commons Attribution CC BY. 


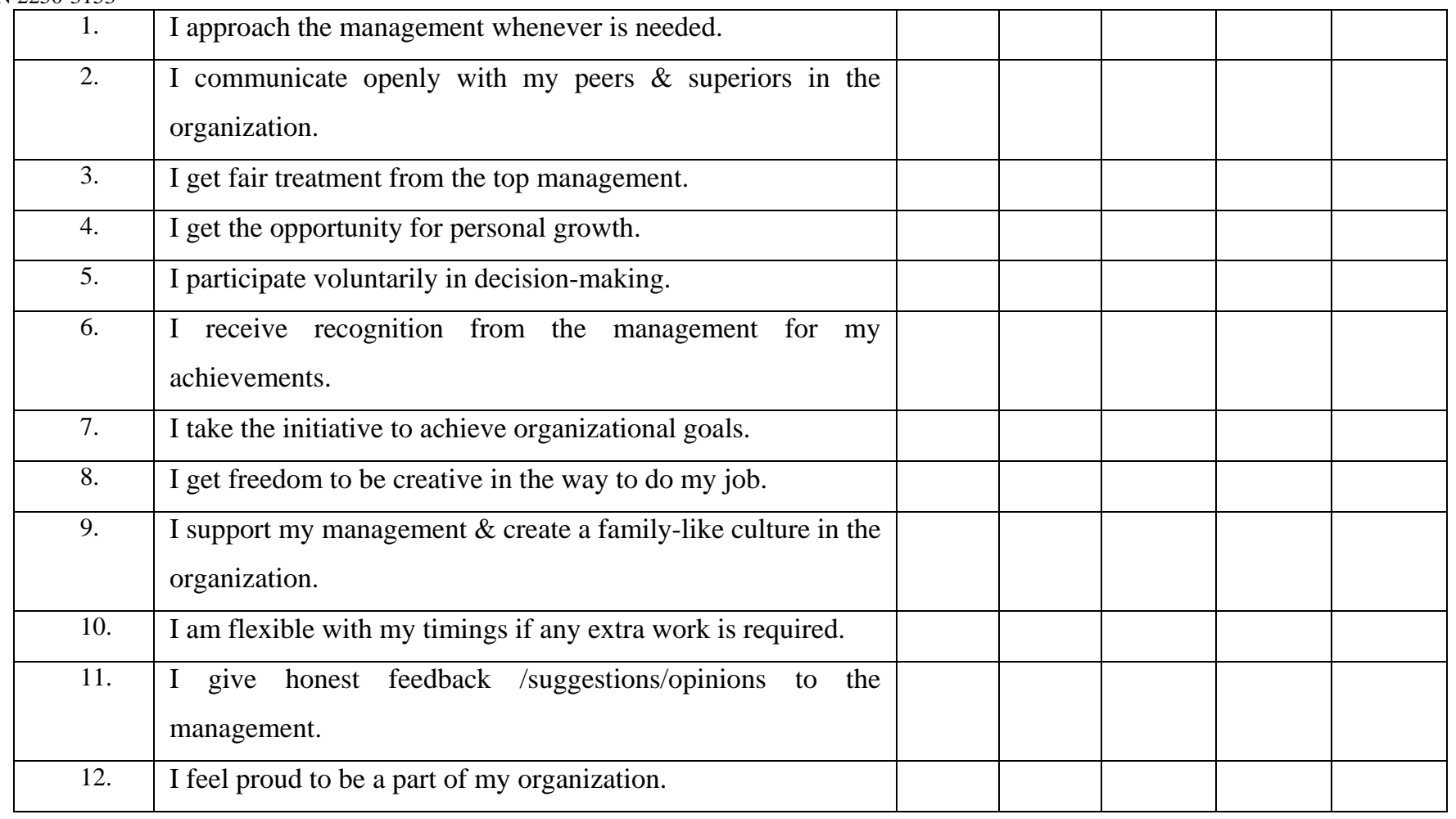

\section{Psychological Contract Questionnaire (Part B) (Employer's obligations towards Employees) SECTION A (Demographic and some other characteristics)}

1. Email Id:

2. Name of the organization:

3. Name of the respondent:

4. Designation:

5. Year of joining the organization:

6. Gender:

Male

$\square$ Female

7. Marital Status:

Unmarried

Married

Other

8. Educational Qualification: Graduate $\square$ Post Graduate

$\mathrm{Ph} \mathrm{D} \square$ Others

9. Age: 25 - 30 years $\square$

30 - 35 years

$35-40$ years

Above 40 years

10. In which sector are you working?

Public Sector

Private Sector

Semi - Government Sector

11. Total working experience: 

0 - 5 years
5 - 10 years
10 - 15 years
15 - 20 years

More than 20 years

12. Number of organizations worked for prior to this organization:

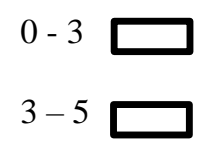

More than 5

\section{SECTION B}

The following table contains items measuring Employers' Commitment/Obligation towards Employees. Please tick the degree to which you think the following statements are applicable for you / in your organization:

\begin{tabular}{|ccccc|}
\hline 1 & 2 & 3 & 4 & 5 \\
Strongly disagree & Disagree & Neutral & Agree & Strongly agree \\
\hline
\end{tabular}

\begin{tabular}{|c|c|c|c|c|c|c|}
\hline S. No. & Obligations & 1 & 2 & 3 & 4 & 5 \\
\hline 1. & $\begin{array}{l}\text { The organization provides competitive compensation to the } \\
\text { employees for their work. }\end{array}$ & & & & & \\
\hline 2. & The organization provides job security to the employees. & & & & & \\
\hline 3. & $\begin{array}{l}\text { The organization provides the opportunity to learn and develop } \\
\text { professional capabilities by "on the job training". }\end{array}$ & & & & & \\
\hline 4. & $\begin{array}{l}\text { The organization provides the opportunities to participate in } \\
\text { decision making (whenever required) to the employees. }\end{array}$ & & & & & \\
\hline 5. & $\begin{array}{l}\text { The organization provides the job assignments that would help } \\
\text { in enhancing the career of the Employees. }\end{array}$ & & & & & \\
\hline 6. & $\begin{array}{l}\text { Employees received a formal performance appraisal during the } \\
\text { past year in our organization. }\end{array}$ & & & & & \\
\hline 7. & $\begin{array}{l}\text { The organization provides opportunities for promotion to the } \\
\text { employees. }\end{array}$ & & & & & \\
\hline 8. & $\begin{array}{l}\text { The organization provides the platform for growth \& overall } \\
\text { development for the employees. }\end{array}$ & & & & & \\
\hline 9. & $\begin{array}{l}\text { The organization is concerned about the personal welfare of the } \\
\text { employees. }\end{array}$ & & & & & \\
\hline 10. & Organization is open for suggestions / feedback / complaints. & & & & & \\
\hline
\end{tabular}




\begin{tabular}{|c|l|l|l|l|l|}
\hline 11. & $\begin{array}{l}\text { The organization provides a forum for recreational activities } \\
\text { for the employees. }\end{array}$ & & & & \\
\hline 12. & $\begin{array}{l}\text { The organization provides the opportunity to vary their work } \\
\text { schedule to the employees. }\end{array}$ & & & & \\
\hline
\end{tabular}

